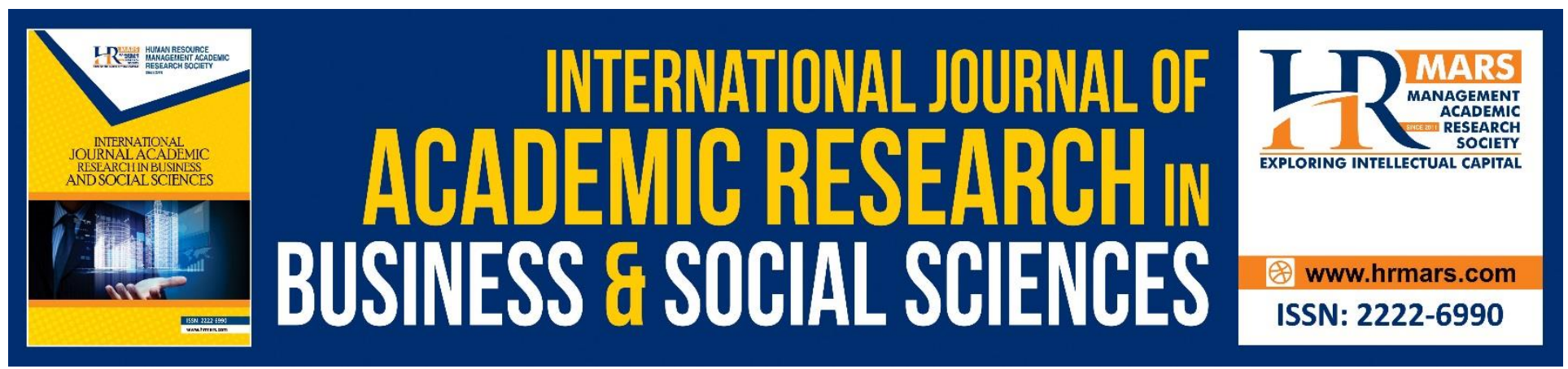

\title{
The Effects of Da'wah Approach through Multimedia Students of Sultan Zainal Abidin University (UniSZA)
}

Zamri Chik, Abdul Hakim Abdullah

To Link this Article: http://dx.doi.org/10.6007/IJARBSS/v8-i11/4961

DOI: $10.6007 /$ IJARBSS/v8-i11/4961

Received: 13 Oct 2018, Revised: 01 Nov 2018, Accepted: 16 Nov 2018

Published Online: 21 Nov 2018

In-Text Citation: (Chik \& Abdullah, 2018)

To Cite this Article: Chik, Z., \& Abdullah, A. H. (2018). The Effects of Da'wah Approach through Multimedia Students of Sultan Zainal Abidin University (UniSZA). International Journal of Academic Research in Business and Social Sciences, 8(11), 846-856.

\section{Copyright: (C) 2018 The Author(s)}

Published by Human Resource Management Academic Research Society (www.hrmars.com)

This article is published under the Creative Commons Attribution (CC BY 4.0) license. Anyone may reproduce, distribute, translate and create derivative works of this article (for both commercial and non-commercial purposes), subject to full attribution to the original publication and authors. The full terms of this license may be seen

at: http://creativecommons.org/licences/by/4.0/legalcode

Vol. 8, No. 11, 2018, Pg. 846 - 856

http://hrmars.com/index.php/pages/detail/IJARBSS

JOURNAL HOMEPAGE

Full Terms \& Conditions of access and use can be found at http://hrmars.com/index.php/pages/detail/publication-ethics 


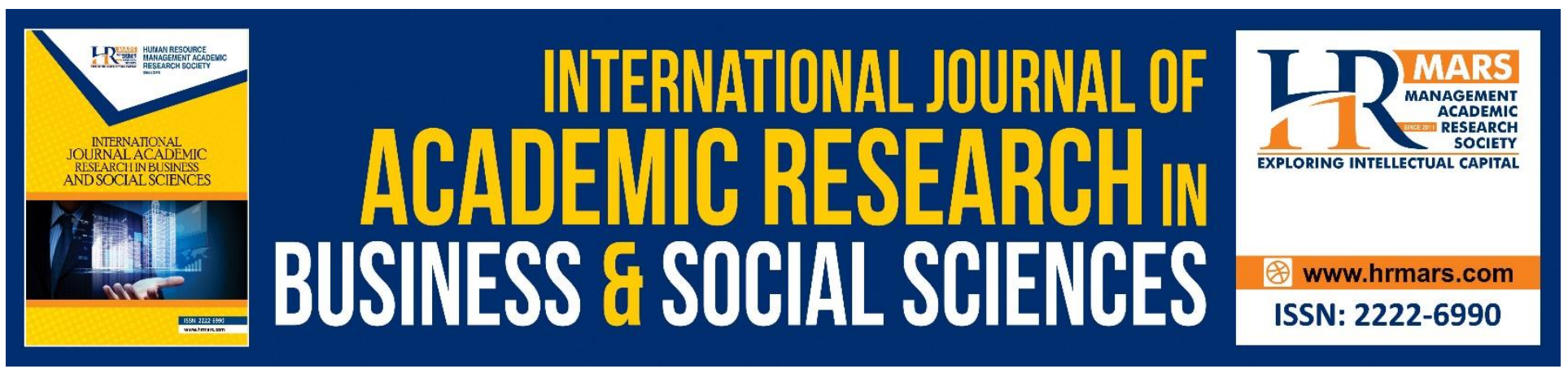

\title{
The Effects of Da'wah Approach through Multimedia Students of Sultan Zainal Abidin University (UniSZA)
}

\author{
Zamri Chik, Abdul Hakim Abdullah \\ Faculty of Islamic Contemporary Studies, Universiti Sultan Zainal Abidin, Gong Badak Campus, \\ 21300 Kuala Terengganu, Terengganu, Malaysia
}

\begin{abstract}
The use of multimedia in life is a very important thing in life, especially university students. Some can not live without a lot of multimedia that alters the lifestyle. Various things are derived from the use of multimedia, such as viewing videos, listening to music, reading articles and so on from multiple platforms. However, multimedia facilities can also invite various things that are not good if it is wrong to use them. UniSZA students prefer to enjoy multimedia through Facebook platforms rather than conventional platforms. Hence, da'wah in the present time has a huge challenge among university students. Without proper approach, da'wah by using multimedia has no significant effect. The research method used in this study is quantitative, test the effectiveness of da'wah approach through text, image, and video and through the facebook platform as intermediary among university students. The purpose of this study is to determine the effectiveness of da'wah approaches that are favoured by university students. A total of 250 UniSZA students are used as a sample using facebook in their lives. The data analysis method used is Structure Equation Model (SEM) using Amos-SEM software. The findings show that the facebook platform has a significant impact on the student's interest in da'wah approach through multimedia. Videos, pictures and texts have a significant impact on the Facebook platform. The results of this study can be used as a reference by Muslim practitioners both individuals and institutions who want to carry out da'wah through multimedia that has a positive impact.
\end{abstract}

Keywords: Amos-SEM, Da'wah Approach, Multimedia

\section{Introduction}

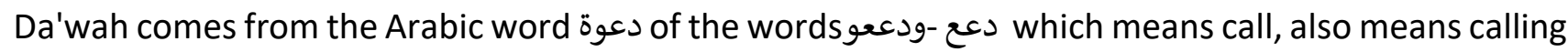
activity and convincing others to accept certain beliefs (Dewan Bahasa Pustaka, 2014). Barghuts (1995) defines da'wah as "systematic and structured hard work aimed at introducing the essence of Islam to all human beings". While Mahfudz (1979: 17) defines da'wah with the terms below: Means: The effort to bring humanity to do good, follow the instructions, to direct them to "amar ma'ruf nahi munkar" so that they can achieve happiness in this world and hereafter. Shihab (1992) defines da'wah 
as a loyalty call to make the situation worse and better for ourselves and society. Whereas Omar (2004) defines da'wah is an attempt to invite people in a wise way to the true path in accordance with the Lord's command for the good of the world and the hereafter. Another Islamic scholar, Sulthon (2003: 9) explains that da'wah is an attempt to persuade others to believe in Allah SWT. Believers intend to obey his orders and leave their prohibitions. Including believing the Prophet, believing in Angels, believing in the Qur'an, believing in the Day of Judgment and believing that good and bad provisions come from Allah SWT. If Allah gives his brother a science and a law (knowledge and charity) then he should immediately convey goodness through the method of da'wah, by inviting people to return to the path of Allah with a clear argument based on the evidence of the greatness of Allah SWT. Because this is the word of the Prophet Muhammad. Allah SWT: Say: This is my way: I call upon Allah, I and those who follow me, and glory to Allah, and I am not an idolater. (Surah Yusuf 12: 108)

He also said that Allah SWT will raise the level of people who call the ways of Allah compared to other classes. Allah SWT says: And who is better than he who calls to Allah when he does well, and says: 'I am the one who surrendered?' (Surah Fussilat 41:33).

Da'wah is a duty for every Muslim and the command of this da'wah has been explained by Allah SWT in surah Ali Imran: You are the best of the nations raised for the benefit of men; you order what is right and forbid wrong and believe in Allah; and if the followers of the Book are sure to be better for them; of them are believers, and most of them are wrong-doers. (Surah Ali Imran 3: 110)

Da'wah is not only responsible for Ulama, Ustaz, fuqaha, or other Islamic experts, but da'wah is required for all Muslims around the world (Fariza, Kalthom \& Puziah, 2016), according to Zaid (2017), in delivering dakwah message, methods and strategies of da'wah. Especially in this era of information technology where everyone depends on it, including multimedia that has changed many things in our lives. We can listen to music, view pictures, and watch videos from multiple platforms. However, for most modern societies, multimedia is more likely to be used for entertainment only. Some misuse it to do something that harms others. According to Al-Ghamidi (2008) a Muslim when he sees something bad, then as much as possible he should try to prevent or fix it according to his level of ability. Conveying the truth of Islam to humanity using the latest technology should be a priority for both individual and institutional speakers. Every Muslim has the obligation to convey the truth of Islam with the language of his people, and today the language is described as information technology.

According to Adam, Anuar \& Ali (2014), the existence of digital-based information technology has made space online especially blogging as the most productive place to deliver religious messages. They consider that the blog acts as an information publisher immediately and accessible. They conducted this study in Malaysia, and they found the fact that although blogs have been widely used as a tool for Islamic teaching, the use of this media has not been fully accepted by some Islamic teenagers due to various factors. In the next study, Adam, Ali, Anuar \& Ali (2015) in his study titled "New Media Challenges As Religion Learning Areas and Their Solution From Islamic Perspective" presents some aspects of goodness in the new internet - media-based (whether through blogs, 
Facebook, twitter and so on) is done with the aim of spreading da'wah to the user. Because the contribution of the internet is an important platform based on the need to implement da'wah and can become a powerful da'wah weapon. This study is almost like discussing new media, but does not analyse the efficacy of da'wah through new media.

There is also a study on "Counterfeiting Using New Media and How to Control it". There are major issues that can be tied to the problem of using new media among consumers in terms of the purpose of using and the authenticity of information according to Islam (Nazim, 2015). He found that there were two new media problem factors among consumers; 1 - The non-mahram relationship of men and women without supervision in cyberspace. 2- Some information and news in new media do not use source legality techniques.

Therefore, this study will discuss the effectiveness of da'wah approach through multimedia and social media (Facebook) among UniSZA students located in Kuala Nerus, Terengganu, Malaysia.

\section{Research Methodology Research Design}

This study is a quantitative study that examines the effectiveness of da'wah approach through text, image and video based on facebook platform as mediator among UniSZA students. The purpose of this study is to determine the effectiveness of the da'wah approach that the UniSZA students are interested in. The sample of this study was a total of 300 UniSZA students using social media and using questionnaires as a research instrument for data collection. Questionnaires were built using Google application forms (Google form apps). Data analysis using Amos Structural Equation Model (SEM).

\section{Research Model}

Figure 1 shows a three independent variable model (Text, Picture and Video), one mediator (Facebook) and one dependent variable (Da'wah Approach). Figure 2 shows the questionnaire items involved in the model of the study. 


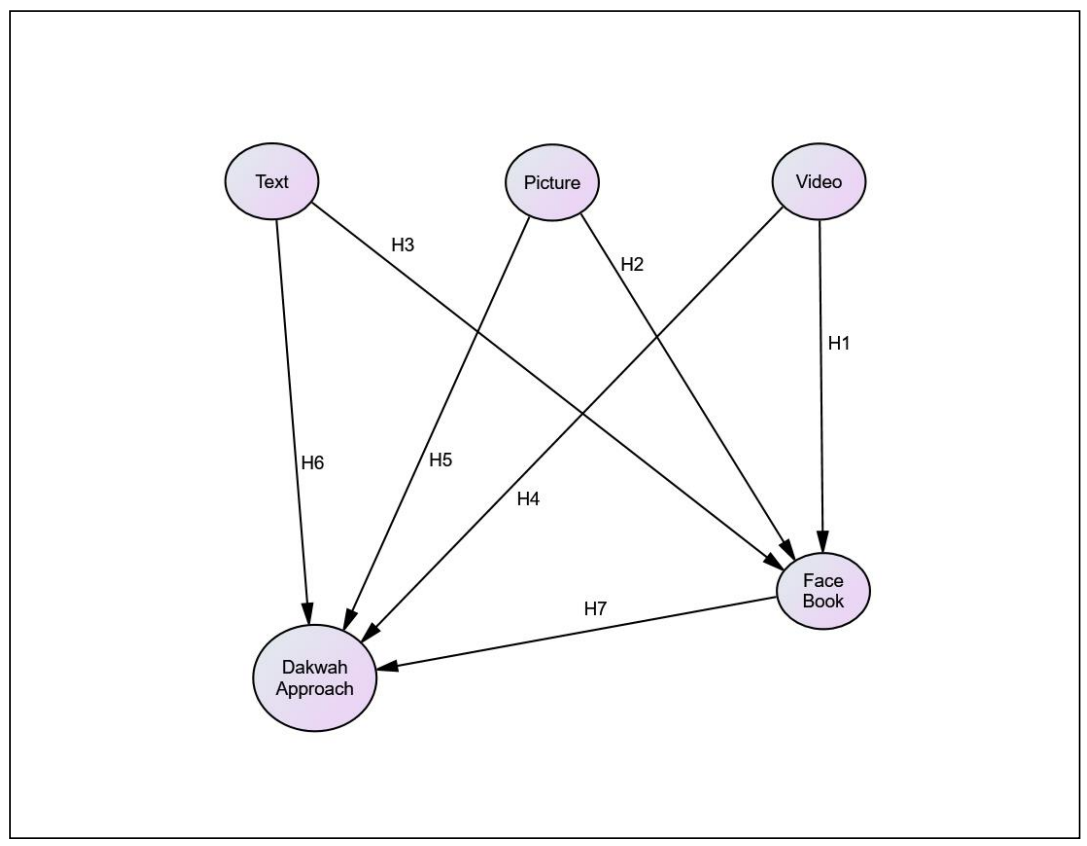

Figure 1: Research Framework

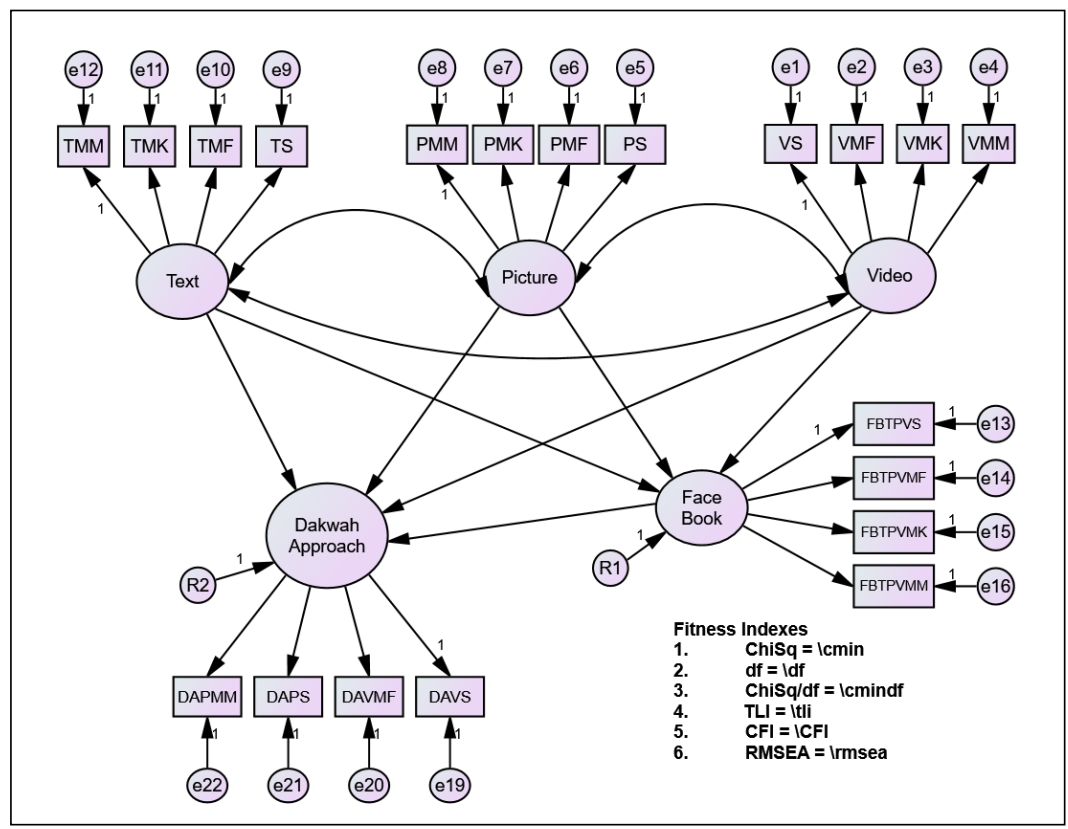

Figure 2: Research Model SEM

\section{Research Findings and Discussions}

We need to implement a proven strategy to achieve da'wah through multimedia successfully, a proven strategy must be an important point for da'wah practitioners. According to Saputra, Nazim \& Islamiyah (2017), da'wah strategy through multimedia requires an accurate introduction to the reality of modern society, so that strategies implemented are not out of date, rigid and adaptable to the needs of times. However, the principle of da'wah according to the Al-Quran and Hadith should also 
INTERNATIONAL JOURNAL OF ACADEMIC RESEARCH IN BUSINESS AND SOCIAL SCIENCES

Vol. 8, No. 11, Nov, 2018, E-ISSN: 2222-6990 @ 2018 HRMARS

be implemented. Based on this study, there are three independent variable constructs (Text, Picture and Video) and a dependent variable (Da'wah Approach). Construct Facebook serves as a mediator that serves as an intermediary of independent variable constructs with dependent variable constructs.

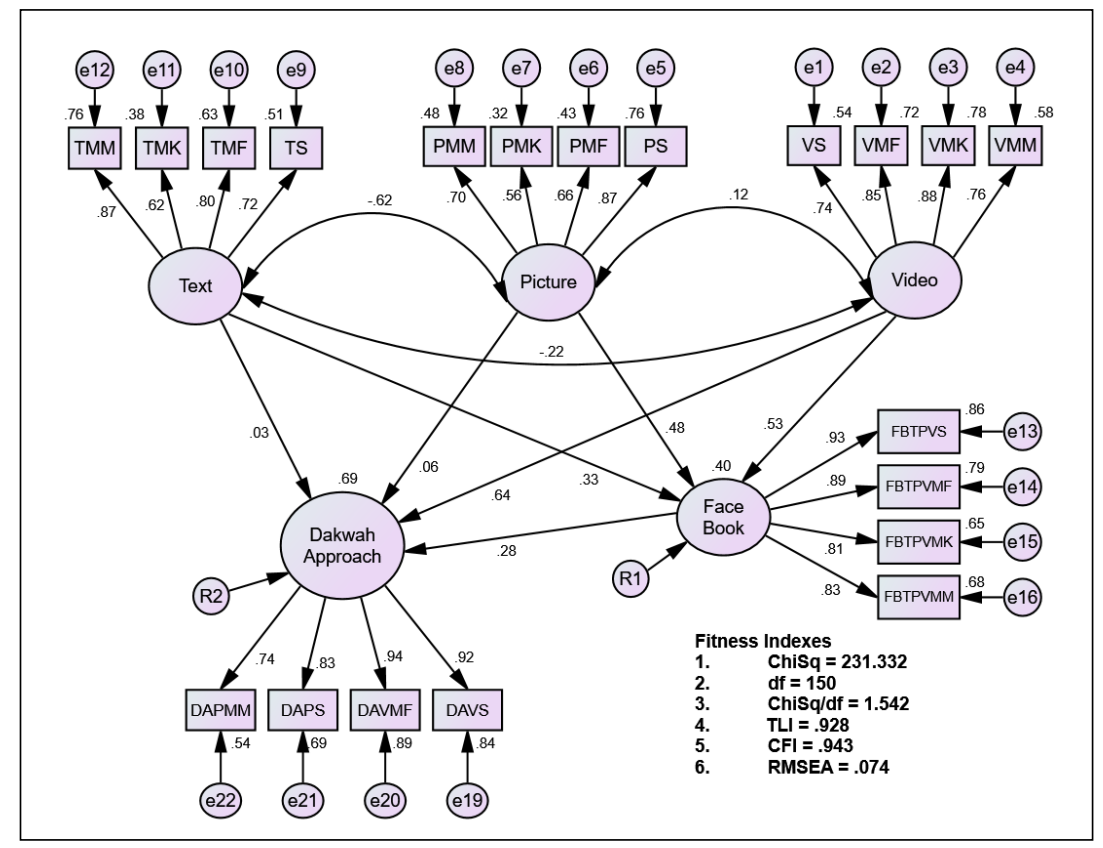

Figure 3: Output Model SEM

Based on the above results, videos, pictures and texts have a significant impact on Facebook development, while video and facebook have a significant impact on Dakwah Approach. The Video Platform has had a great impact on Dakwah Approach. To assess the impression of mediation, the Step-Wise approach was used (Baron \& Kenny, 1986).

Table 1: Analysis Results

\begin{tabular}{|c|l|l|c|c|c|c|c|}
\hline Construct & & Construct & Estimate & S.E. & C.R. & P & Result \\
\hline Face_Book & $<---$ & Video & 0.351 & 0.072 & 4.890 & 0.001 & Significant \\
\hline Face_Book & $<---$ & Picture & 0.881 & 00.262 & 3.360 & 0.001 & Significant \\
\hline Face_Book & $<---$ & Text & 0.578 & 0.237 & 2.440 & 0.015 & Significant \\
\hline Dakwah_Approach & $<---$ & Video & 0.441 & 0.077 & 5.705 & 0.001 & Significant \\
\hline Dakwah_Approach & $<---$ & Face_Book & 0.292 & 0.102 & 2.866 & 0.004 & Significant \\
\hline Dakwah_Approach & $<---$ & Picture & 0.118 & 0.219 & 0.540 & 0.589 & Not Significant \\
\hline Dakwah_Approach & $<---$ & Text & 0.060 & 0.194 & 0.310 & 0.757 & Not Significant \\
\hline
\end{tabular}


INTERNATIONAL JOURNAL OF ACADEMIC RESEARCH IN BUSINESS AND SOCIAL SCIENCES Vol. 8, No. 11, Nov, 2018, E-ISSN: 2222-6990 @ 2018 HRMARS

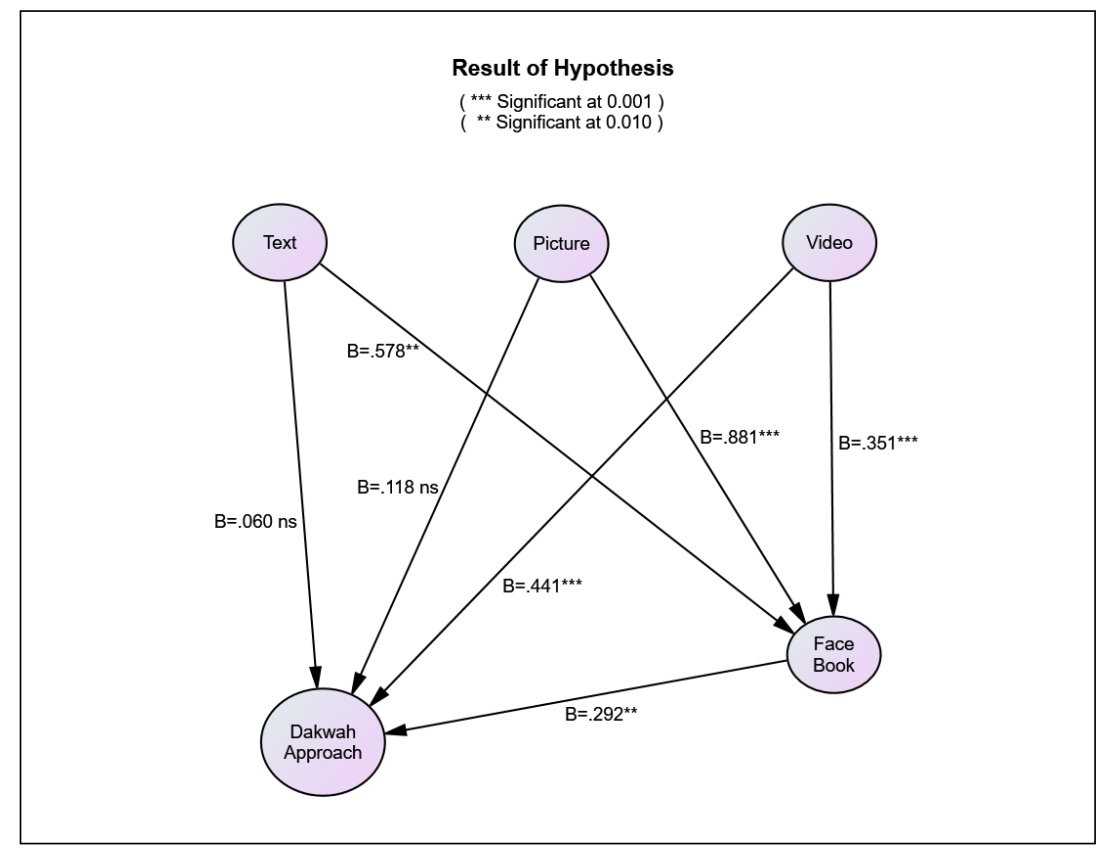

Figure 4: Result of Hypothesis

Mediation is said to exist when indirect effects are greater than direct effects (Awang, 2015; Awang, Afthanorhan, Mohamad \& Asri, 2015a). Figure 5 shows that Facebook mediators do not apply in the relationship between Video and Da'wah Approach, because the value of the indirect effects is less than the direct effects $(0.53 \times 0.28=0.1484<0.64)$.

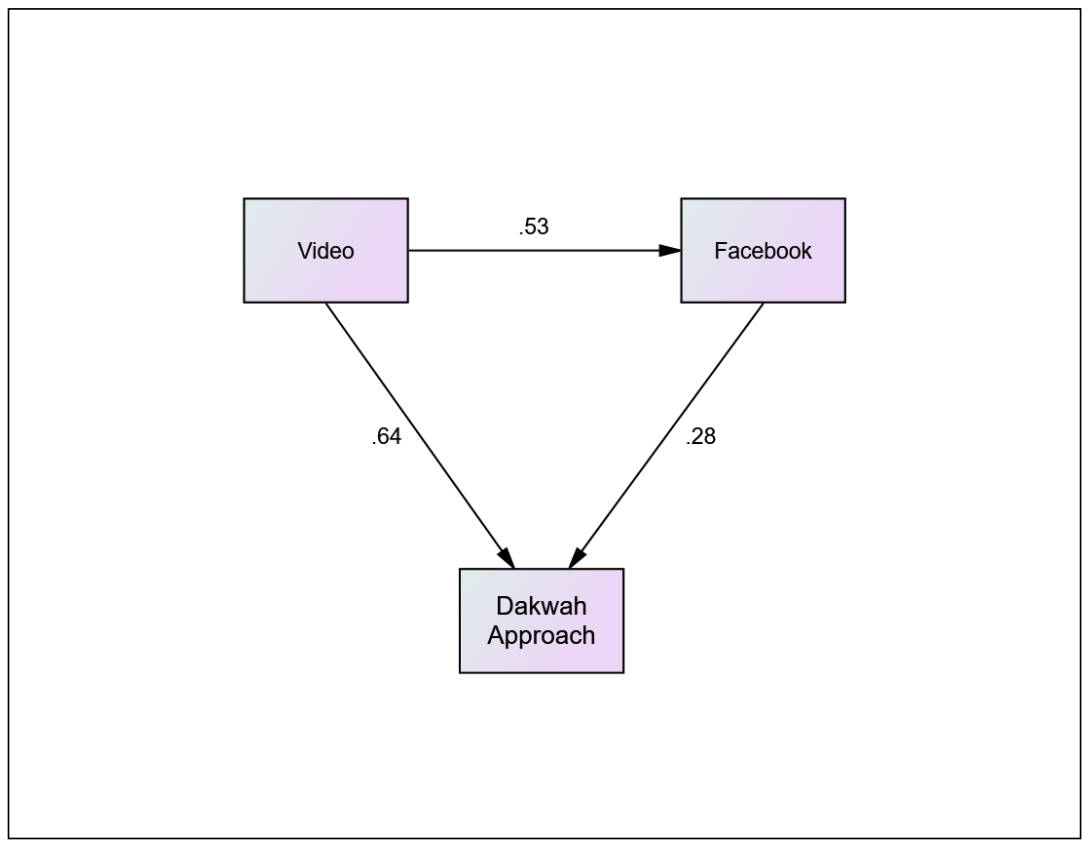

Figure 5: Mediator Facebook between Video and Dakwah Approach 
INTERNATIONAL JOURNAL OF ACADEMIC RESEARCH IN BUSINESS AND SOCIAL SCIENCES Vol. 8, No. 11, Nov, 2018, E-ISSN: 2222-6990 @ 2018 HRMARS

Figure 6 shows the Facebook mediator occurring in the relationship between Picture and Da'wah Approach, as the indirect effects value is greater than the result of the direct effects $(0.48 \times 0.28=$ $0.1248>0.06)$.

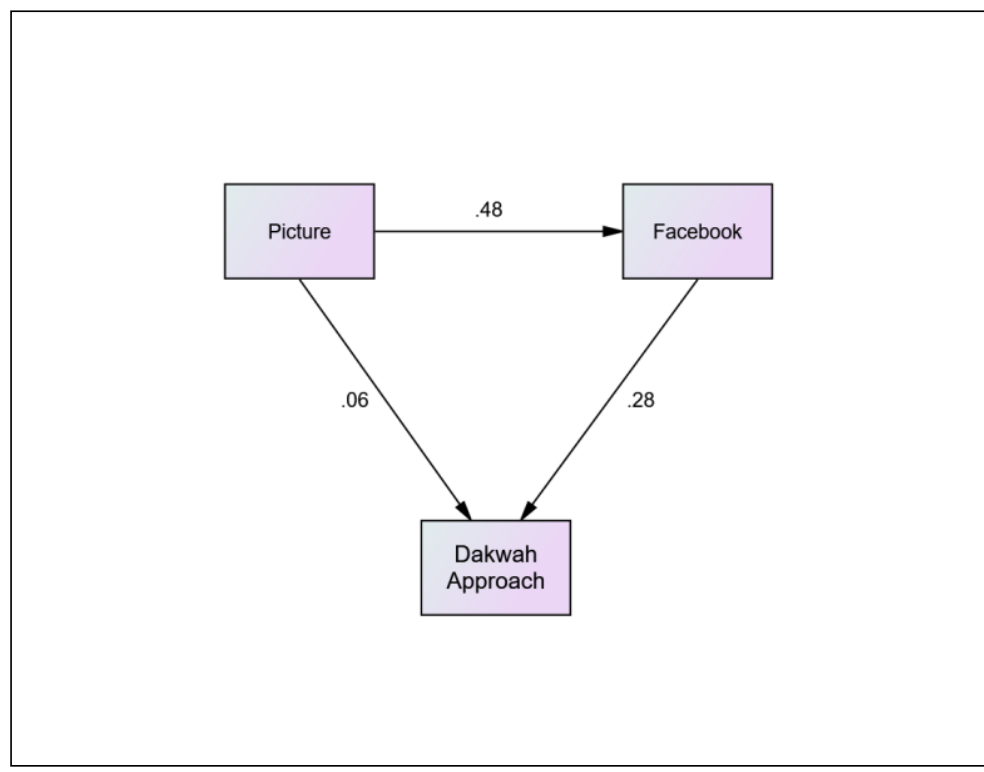

Figure 6: Mediator Facebook between Picture and Dakwah Approach

Figure 7 shows Facebook mediators occurring in the relationship between Text and Da'wah Approach, because the value of the indirect effects is greater than the direct effects $(0.33 \times 0.28=$ $0.0924>0.03)$.

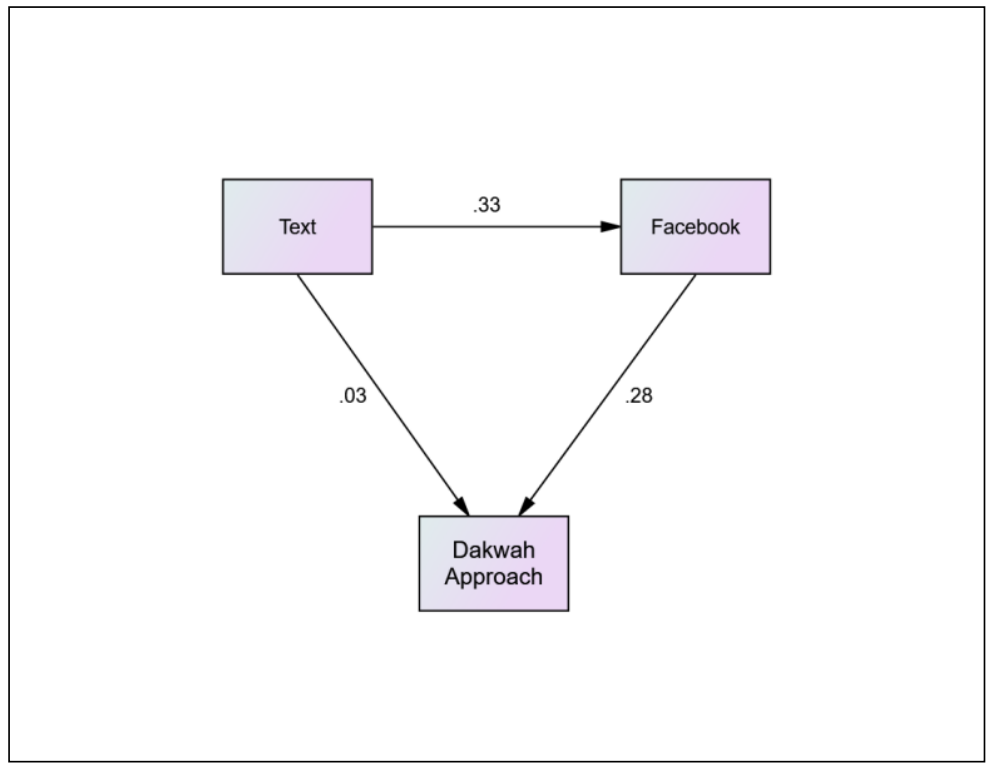

Figure 7: Mediator Facebook between Text and Dakwah Approach 


\section{Conclusion}

This study proves that multimedia content (video, pictures, and texts) has a significant impact and positive impact through social media (Facebook). This means that UniSZA students prefer to enjoy the multimedia dakwah content through Facebook platforms rather than conventional platforms. This study also proves that video and Facebook have a significant impact on Dakwah approach. But the video is the most important thing that can have a big impact on Da'wah Approach even without using the Facebook platform. However, through Facebook's image platform (picture, graphic or infographic) and text has a significant impact on da'wah approach.

Multimedia and social media (Facebook) have changed many things in our lives. We need to use da'wah approach because everyone can not ignore it. If more people know how to do da'wah through multimedia, we can produce and multiply the positive effects of Islamic content in cyberspace, especially in social media (Facebook). While offering so many facilities, multimedia can be very dangerous for UniSZA students in the development of social media. As a result if this domain can not be controlled by da'wah practitioners, future generations of Islam will be far from religion.

\section{Acknowledgement}

Special appreciation is owed to Universiti Sultan Zainal Abidin (UniSZA), Research Management, Innovation \& Commercialization Centre (RMIC) UniSZA \& Ministry of Higher Education Malaysia (MOHE).

\section{Corresponding Author}

Abdul Hakim Abdullah

Faculty of Islamic Contemporary Studies, Universiti Sultan Zainal Abidin, Gong Badak Campus, 21300 Kuala Nerus, Terengganu, Malaysia. Email: hakimabd@unisza.edu.my

\section{References}

Adam, F., Ali, A. H., Anuar, M. M., \& Ali, E. M. T. E. (2015). Cabaran Media Baru Sebagai Medium Pembelajaran Agama dan Penyelesaiannya dari Perspektif Islam. Jurnal Islam Dan Masyarakat Kontemporari, 9, 101-139.

Adam, F., Anuar, M. M., \& Ali, A. H. (2014). The Use of Blog as a Medium of Islamic Dakwah in Malaysia. International Journal of Sustainable Human Development, 2(2), 74-80.

Afthanorhan, A., Awang, Z., \& Fazella, S. (2017). Developing the patients' loyalty model for medical tourism industry: the case of Malaysia. International Journal of Society Systems Science, 9(2), 139-164.

Alawi, A. (2013). NU Online adalah Karomah NU. NU Online.

Al-Ghamidi, A. bin A. A.-'Alaf. (2008). Kiprah Dakwah Muslimah Melejitkan Semangat Muslimah dalam Berdakwah (Kuni Da'iyatan, Nashaih, Taujihat, Tajarib, Iqtirahat fi AdDa'wati Ilallah). (A. Syarifuddin, Al-Marfu'i, \& Dhiyaulhaq, Eds.). Solo: Pustaka Arafah.

Awang, Z. (2015). SEM Made Simple: A Gentle Approach to Learning Structural Equation Modelling. Bandar Baru Bangi, MPWS Rich Resources. 
INTERNATIONAL JOURNAL OF ACADEMIC RESEARCH IN BUSINESS AND SOCIAL SCIENCES

Vol. 8, No. 11, Nov, 2018, E-ISSN: 2222-6990 @ 2018 HRMARS

Awang, Z., Afthanorhan, A., Mohamad, M., \& Asri, M. A. M. (2015a). An evaluation of measurement model for medical tourism research: the confirmatory factor analysis approach. International Journal of Tourism Policy, 6(1), 29-45.

Barghuts, T. (1995). Manhaj Al-Nabiy fi Himayat al-Dakwah WA Al-Muhafadhah 'ala Munjazatiha Khilal al-Fatrah al-Makkiyah. USA.

Baron, R. M., \& Kenny, D. A. (1986). The moderator-mediator variable distinction in social psychological research: Conceptual, strategic, and statistical considerations. Journal of Personality and Social Psychology, 51(6), 1173.

Chik, Z., \& Abdullah, A. H. (2018). Developing and validating instruments for measurement of motivation, learning styles and learning disciplines for academic achievement. International Journal of Academic Research in Business and Social Sciences, 8(4), 594-605.

(2018). Effect of motivation, learning style and discipline learn about academic achievement additional mathematics. International Journal of Academic Research in Business and Social Sciences, 8(4), 772-787.

Chik, Z., \& Abdullah, A. H., Muda, H., Istikomah (2018). Peranan faktor demografik dalam hubungan antara motivasi, gaya pembelajaran, disiplin pembelajaran dan pencapaian akademik pelajar. Islamic Education Journal 2 (1), 88-103.

Chmura Kraemer, H., Kiernan, M., Essex, M., \& Kupfer, D. J. (2008). How and why criteria defining moderators and mediators differ between the Baron \& Kenny and MacArthur approaches. Health Psychology, 27(2S), S101.

Dewan Bahasa Pustaka. (2014). Kamus Dewan. Kuala Lumpur: Dewan Bahasa Pustaka.

Fariza Hanan, M., Kalthom, H., \& Puziah, A. W. (2016). Uslub Dakwah Menurut Perspektif Islam. In Seminar Antarabangsa Akidah, Dakwah Dan Syariah 2016 (Irsyad 2016) (pp. 869-884).

Karim, A. B. A. A. (2012). Ushul Ad-Dakwah As-Salafiyah. Darul Minhaj.

Kashif, M., Awang, Z., Walsh, J., \& Altaf, U. (2015). I'm loving it but hating US: understanding consumer emotions and perceived service quality of US fast food brands. British Food Journal, 117(9), 2344-2360.

Kashif, M., Samsi, S. Z. M., Awang, Z., \& Mohamad, M. (2016). EXQ: measurement of healthcare experience quality in Malaysian settings: A contextualist perspective. International Journal of Pharmaceutical and Healthcare Marketing, 10(1), 27-47.

Kashif, M., Kashif, M., Braganca, E., Braganca, E., Awang, Z., Awang, Z., \& Cyril De Run, E. (2017). You abuse but I will stay: The combined effects of job stress, customer abuse, and emotional intelligence on employee turnover. Journal of Management Development, 36(7), 899-914.

Mahfudz, A. (1979). Hidayatu al-Mustarsyidin ila al-Thuruq al-Wa'dhli wa al-Khatabah. Dar AlI'thisham.

Mohamad, M., Mohammad, M., Mat Ali, N. A., \& Awang, Z. (2016a). The impact of life satisfaction on substance abuse: delinquency as a mediator. International Journal of Adolescence and Youth, 1-11.

Nazim, A. B. M. (2015). Salah laku Penggunaan Media Baharu dan Adab Mengatasinya. Terengganu. Omar, T. Y. (2004). Islam dan dakwah. Jakarta: Al-Mawardi Prima. 
Saputra, R., Nazim, A. M., \& Islamiyah, U. H. (2017). Dakwah Strategy 'Persaudaraan Professional Muslim (PPM) Aswaja' through the Internet. International Journal of Academic Research in Business and Social Sciences, 7(6), 797-803. https://doi.org/10.6007/IJARBSS

Shihab, M. Q. (1992). Membumikan Al-Quran. Bandung: Mitra Pustaka.

Sulthon, M. (2003). Desain Ilmu Dakwah. Yogyakarta: Pustaka Pelajar.

Ulinnuha, A. A. (2009). Strategi Dakwah PBNU melalui Website www.nu.or.id. UIN Syarif Hidayatullah.

Yusof, Y., Awang, Z., Jusoff, K., \& Ibrahim, Y. (2017). The influence of green practices by non-green hotels on customer satisfaction and loyalty in hotel and tourism industry. International Journal of Green Economics, 11(1), 1-14.

Zaid, I. (2017). Uslub, Manhaj dan Wasilah Dakwah. Retrieved 10 November 2017, from http://ibnzahid.blogspot.my/2007/03/uslubmanhaj-dan-wasilah-dakwah.html 